\title{
Hox Genes in Reptile Development, Epigenetic Regulation, and Teratogenesis
}

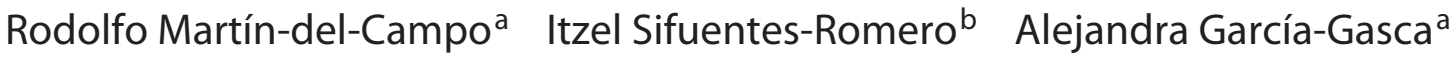 \\ a Laboratory of Molecular Biology, Centro de Investigación en Alimentación y Desarrollo (CIAD), Mazatlán, Mexico; \\ ${ }^{b}$ Department of Biological Sciences, Florida Atlantic University, Boca Raton, FL, USA
}

\section{Keywords}

Body plans · Congenital malformations · Epigenetic regulation $\cdot$ Hox genes $\cdot$ Reptiles

\begin{abstract}
Reptiles are ancestral organisms presenting a variety of shapes, from the elongated vertebral column of the snake to the turtle dorsalized ribs or retractile neck. Body plans are specified by a conserved group of homeobox-containing genes (Hox genes), which encode transcription factors important in cell fate and vertebral architecture along the anteroposterior axis during embryonic development; thus, dysregulation of these genes may cause congenital malformations, from mild-sublethal to embryonic-lethal. The genetic pool, maternal transfer, and environmental conditions during egg incubation affect development; environmental factors such as temperature, moisture, oxygen, and pollution may alter gene expression by epigenetic mechanisms. Thus, in this review, we present information regarding Hox genes and development in reptiles, including sex determination and teratogenesis. We also present some evidence of epigenetic regulation of Hox genes and the role of the environment in epigenetic modulation of gene expression. So far, the evidence suggests that the molecular instructions
\end{abstract}

\section{KARGER}

๑ 2018 S. Karger AG, Basel

E-Mail karger@karger.com

www.karger.com/cgr encoded by Hox genes to build a snake, a lizard, or a turtle represent the interplay between genome and epigenome after years of evolution, with occasional environmentally induced molecular mistakes leading to abnormal body shapes.

(c) 2018 S. Karger AG, Basel

Living reptiles are classified in 4 different orders, Testudines (turtles), Crocodilia (alligators and crocodiles), Squamata (amphisbaenians, lizards, and snakes), and Rhynchocephalia (the tuatara, Sphenodon). The body plan is sculpted from the germinal layers; bilaterally paired blocks (somites) along the anteroposterior axis of the developing embryo will be formed from the paraxial mesoderm by means of somitogenesis [Gilbert, 2010]. The differentiation of organs begins with neurulation, in which the neural tube and the neural crest form, culminating with the development of extraembryonic membranes and organs. Once organs and tissues are differentiated, growth occurs with dramatic increases in embryo size and changes in the size and configuration of extraembryonic membranes [Deeming and Ferguson, 1991].

Experimental studies suggest 3 types of molecules acting during body plan formation in vertebrates: (1) secreted signaling molecules/growth factors, (2) signaling inter-

Alejandra García-Gasca

Laboratory of Molecular Biology

Centro de Investigación en Alimentación y Desarrollo (CIAD)

Avenida Sábalo Cerritos S/N, Mazatlán 82110 (Mexico)

E-Mail alegar@ciad.mx 
mediaries (such as kinases), and (3) transcription factors (such as Hox genes) [Schoenwolf and Smith, 2000]. Hox genes are master regulators of embryonic development; they encode homeodomain-containing transcription factors important in the specification of body plans along the anteroposterior axis in animals [Lewis, 1978]. Here, we review Hox gene function during development and sex determination in reptiles as well as epigenetic mechanisms involved in Hox gene regulation. We also describe several cases of congenital malformations reported in reptiles, some of which resemble mutant Hox gene phenotypes obtained in animal models, and the potential role of the environment in the creation of these aberrant shapes.

\section{Hox Genes in Reptile Development}

Expression patterns of Hox genes are related to body plan diversification [Gaunt, 1994; Burke et al., 1995; DiPoï et al., 2010]. The vertebral column in tetrapods originates early in development by a series of occipital somites that compose the base of the skull, followed by cervical, thoracic, lumbar, sacral, and caudal somites [Mallo et al., 2010]. It has been proposed that Hox paralogue genes control complete anatomical axial domains; for example, Hox4 paralogues control the morphology of the cervical region, Hox5-9 the rib cage, Hox10 the lumbar region (and rib suppressor), and Hox11-13 the sacrum and tail [Mallo et al., 2010]. A complete inventory of Hox genes in crocodiles, turtles, snakes, and lizards has been reported [Liang et al., 2011]. In this inventory, all Hox genes known in placental mammals and birds were present in reptiles, except for snakes. In this group, Hoxd12 seemed to be absent, but interestingly, it was present in limbless lizards, and therefore not necessarily related to a digit or limb reduction phenotype. In addition, Hoxc 3 was absent in turtles and crocodiles, but not in lizards and snakes. Based on the presence of Hoxc3 in lobe-finned fishes and amphibians, it was suggested that Hoxc3 is an ancestral state for amniotes.

According to Böhmer and Werneburg [2017], the first Hox gene expressed in the vertebral cervical column of archosaurs was Hoxb5, showing the anterior expression boundary at the axis (cervical vertebra 2 [CV2]). However, in the turtle, the anterior expression boundary of Hoxb5 is at the atlas (CV1). In Pelodiscus sinensis, the atlas is morphologically different from posterior cervical vertebrae, suggesting that the Hox code at CV1 is different from other cervical vertebrae in cryptodiran species (including sea turtles) [Jones et al., 2012].

Hox Genes in Reptile Development
Interestingly, in the same study, Böhmer and Werneburg [2017] reported that in crocodiles, Hoxa5 is expressed at CV9, whereas in P. sinensis, it is expressed at CV2. This anterior expression in the turtle seems to be related to the absence of free cervical ribs, which allows the turtle to retract the head and neck inside the shell. Also interesting, Hoxc8 in crocodiles is expressed at thoracic vertebra 1 (TV1) and in turtles at TV3. The expression of Hoxc8 in the crocodile seems to be related to the development of neural spines from thoracic vertebrae, whereas in the turtle it seems to be related to the loss of the sternum and the modification of ventral ribs to portions of the plastron.

Regarding posterior Hox loci, Di-Poï et al. [2010] compared the genomic organization in Squamata (corn snake, Pantherophis guttatus; gecko, Gekko ulikovski; slow worm, Anguis fragilis, and anole, Anolis carolinensis), Testudines (Trachemys scripta), and tuatara (Sphenodon punctatus), identifying a rather generic distribution of Hox genes (except in the corn snake, which lacks Hoxd12) and the absence of some conserved noncoding elements in all Squamata. Some squamate reptiles (such as snakes) have a very peculiar vertebral formula, with an enormously elongated thorax and extremely narrow cervical, lumbosacral and caudal regions (Fig. 1) [Gomez et al., 2008].

Di-Poï et al. [2010] investigated the expression patterns of Hox genes 10-13 in embryos of the corn snake (which has more than 300 vertebrae) during somitogenesis. These patterns were compared to those of whiptail lizard embryos, which show a comparatively shorter body plan. In the corn snake, neither Hoxa13 nor Hoxd13 were expressed at detectable levels in the mesodermal layers throughout the somitogenic process, except for a weak and transient signal. In contrast, all Hox 13 and Hoxd12 genes were expressed in the bud of the whiptail lizard tail; the expression of these genes has also been identified in other vertebrate amniotes [Gaunt, 1994; Burke et al., 1995]. Thus, Hoxa13 genes may repress posterior axial elongation, and it is possible that the reduction of Hox 13 activity is a key event for the evolution of elongated body plans [Di-Poï et al., 2010; Mallo et al., 2010]. In the whiptail lizard, both Hoxa10 and Hoxc10 genes labeled only the vertebra without ribs, located immediately prior to the sacrum. In the corn snake, the expression of Hoxd10 showed an anterior limit at the level of the first caudal vertebrae (also shown the in whiptail lizard). Thus, DiPoï et al. [2010] corroborated what was identified in other vertebrate amniotes: Hox 10 genes function to suppress rib formation and thus determine the thoracolumbar transition [Burke et al., 1995; Carapuço et al., 2005].

Cytogenet Genome Res 2019;157:34-45 DOI: $10.1159 / 000495712$ 


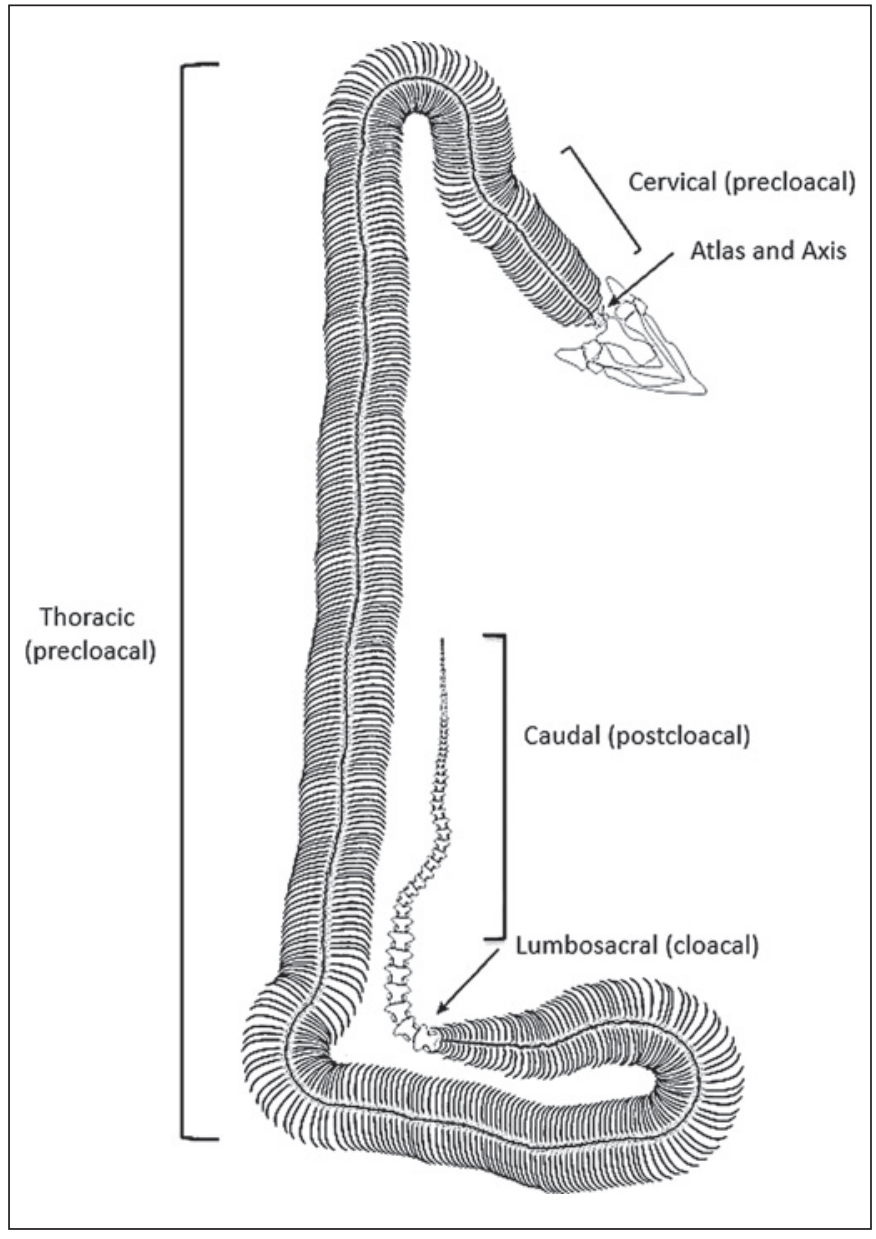

Fig. 1. Vertebral column of a snake. Axial formula (precloacal and postcloacal) are indicated. Illustration drawn by Eric BautistaGuerrero.

Hox genes also appear to be involved in the regionalization of the lateral plate mesoderm into forelimb, flank, and hind limb to specify limb position [Rancourt et al., 1995; Cohn et al., 1997]. A peculiar feature of snakes within the reptile group besides possessing hundreds of vertebrae is that forelimbs are absent and hind limbs are either severely reduced (with just pelvic girdles and rudimentary femurs) or absent. Cohn and Tickle [1999] examined the expression of 3 Hox genes (Hoxc6, Hoxc8, and Hoxb5) in the mesoderm of lateral and paraxial plates of the python. In this region of tetrapods and fish, anterior expression boundaries of all 3 genes occur at the forelimb/pectoral fin level, where they specify shoulder development [Rancourt et al., 1995; Nelson et al., 1996]. However, in python, a sharp posterior boundary of Hoxc8 expression at the level of the hind limbs was detected. Hoxc8 and
Hoxb5 were present in the whole mesoderm of the lateral plate of the python, with the expression ending at the anterior limit of the trunk. Hoxc6 was expressed in somites throughout the entire trunk, extending from the cloacal/ hind limb level to the most anterior somite. Expansion of Hoxc6 and Hoxc8 domains in python in both side plate and parallel plate mesoderm could be one of the mechanisms that transformed the entire snake trunk towards a thoracic/flank identity and led directly to the absence of forelimb development during snake evolution [Cohn and Tickle, 1999]; in other words, the expanded overlapping expression of Hoxc6 and Hoxc8 in python instructs the vertebra to form ribs throughout most of the body, resulting in the absence of forelimbs.

Since the growth of vertebrate limb buds depends on the apical ectodermal ridge (a thickened epithelium bordering the distal edge of limb buds), Cohn and Tickle [1999] also measured gene expression that normally characterizes the apical ridge ( $D l x, F g f 2$, and $M s x)$. In python embryos, no apical ectodermal ridge could be found, and gene expression was not detected in limb ectoderm. More recently, Leal and Cohn [2016] proposed that hind limb development stops in python embryos as a result of mutations that eliminate essential transcription factor binding sites in the limb-specific enhancer of Sonic hedgehog. Consistently, Kvon et al. [2016] demonstrated that through nucleotide-specific changes in the zone of polarizing activity regulatory sequence (ZRS, which is a limb-specific enhancer of Sonic hedgehog) in snakes the ZRS enhancer has progressively lost its function during snake evolution, leading to the disappearance of the limbs. In contrast, according to Leal and Cohn [2016], Hoxd limb enhancers are conserved in the python embryo. Expression of Hoxd13 spreads throughout the distal region of the python hind limb bud, overlapping with Hoxa13 expression in a pattern that resembles digitforming domains of Hoxa13 and Hoxd13 in limbed tetrapods [Montavon et al., 2011]. Therefore, because Hoxd expression in digits and external genitals are under shared regulatory control, it is possible that Hoxd distal enhancers were retained in snakes due to their essential role in external genital development [Lonfat et al., 2014; Leal and Cohn, 2016].

\section{Hox Genes and the Formation of the Turtle Shell}

The turtle shell is an evolutionary novelty restricted to the order Testudines that first appeared in the fossil record 210 MYA [Gaffney, 1990; Gilbert et al., 2008], and
36

Cytogenet Genome Res 2019;157:34-45 DOI: $10.1159 / 000495712$
Martín-del-Campo/Sifuentes-Romero/ García-Gasca 
Fig. 2. Turtle embryo showing the carapacial ridge. A Schematic representation (licensed under Creative Commons Attribution-Share Alike 4.0 International). B Pelodiscus sinensis embryo. Printed from Nagashima et al. [2007] with permission from the authors.

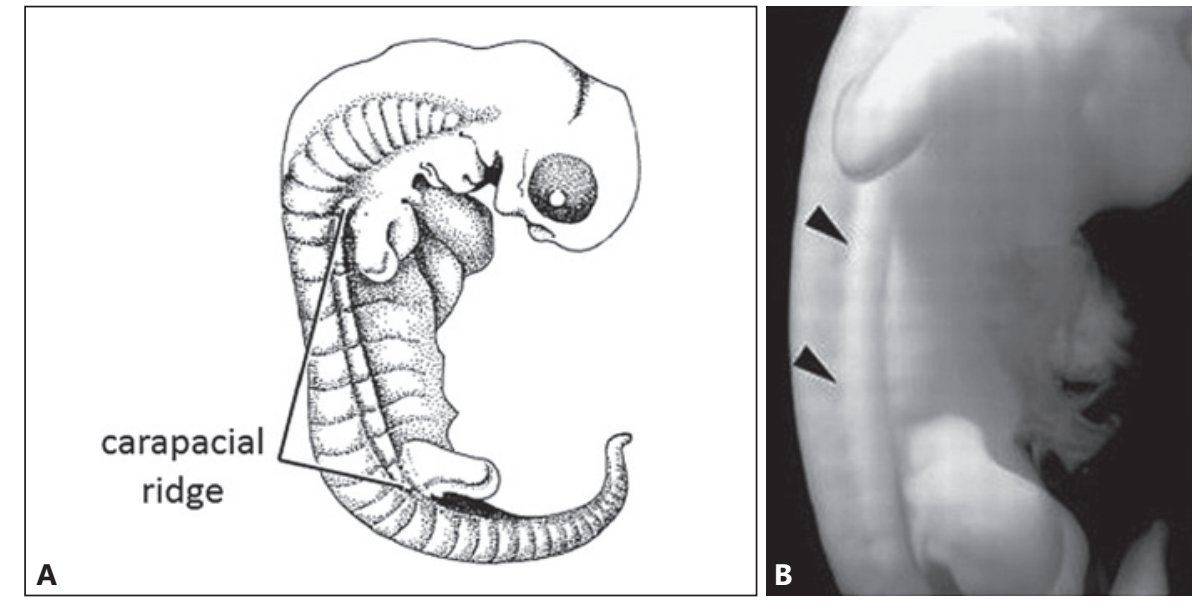

an older record of $220 \mathrm{MY}$ was also identified [Li et al., 2008]. It has been demonstrated that the turtle shell evolved from endoskeleton modifications. Comparative developmental analysis showed that the costal and neural plates are hypertrophied ribs and vertebrae, respectively [Hirasawa et al., 2013].

The turtle shell forms by membranous ossification [Vincent et al., 2003] and holds more than 50 dermal plates, which are unique to this group. This architecture required extensive modifications of the body plan [Gilbert et al., 2001]. The shell consists of 2 main parts, the dorsal carapace and the ventral plastron, which are connected by lateral bridges. The innovative structure seems to be the carapacial ridge, a protuberance of mesenchyme cells in the thoracic region covered by surface ectoderm that plays an essential role in the development of the turtle carapace [Gilbert et al., 2001; Nagashima et al., 2007] (Fig. 2). The carapacial ridge is the leading edge of carapacial primordium, which expands laterally and is followed by the growth of the rib primordia causing the ribs to be dorsalized. The ribs are covered by the dorsal dermis, resulting in lateral displacement as the dermis expands. Instead of extending ventrally (enclosing the thorax), the ribs integrate to the carapacial dermis [Gilbert et al., 2001; Nagashima et al., 2007] (Fig. 3). Differential cDNA screening has revealed that the formation of the carapace depends on carapacial ridge-specific expressed genes, which acquired specific regulatory functions in the turtle linage [Kuraku et al., 2005].

Since Hox genes are responsible for the anteroposterior design in animals, it has been proposed that the Hox code in turtle embryos correlates with the evolutionary innovation of their shell [Ohya et al., 2005]. By comparing the expression of Hoxa5, Hoxb5, Hoxc6, Hoxa7, and

Hox Genes in Reptile Development
Hoxc8 in embryos of the Chinese soft shell turtle P. sinensis with that of chicken and mouse embryos, Ohya et al. [2005] observed that the anterior expression boundaries of Hoxa5 and Hoxb5 were detected at the level of CV2 and CV1, respectively, and Hoxc6 was restricted to the paraxial part of the embryo, with anterior expression boundaries at the level of the TV1; Hoxa7 and Hoxc8 showed anterior expression boundaries at CV6 and TV3, respectively (Fig. 3). Thus, Hox gene expression in P. sinensis presents an anterior shift when compared to chicken and mouse, and these differences are probably related to the turtle-specific trunk developmental program.

More recently, Böhmer and Werneburg [2017] suggested that expression of Hoxc6 (at the cervicothoracic transition) corresponds to the lack of ventral ribs in turtles, since it is expressed in prevertebrae and future carapacial dermis, but not in the somatopleure (region in which ventral ribs are missing). The authors also suggested that $\mathrm{Hoxa} 7$ was recruited for a turtle-specific function because most turtles possess a highly retractile neck that requires specialization at CV8. The exception would be sea turtles, in which neither neck nor limbs are retractile [Jones et al., 2012], probably as an adaptation for feeding and rapid swimming and diving in the marine environment.

\section{Hox Genes in Sex Determination}

The mechanisms of sex determination in reptiles can be divided in 2 types: genotypic sex determination (GSD) and environmental sex determination (ESD) [Rhen and Schroeder, 2010; Merchant-Larios and Díaz-Hernandez, 2013]. Temperature is the only environmental variable

Cytogenet Genome Res 2019;157:34-45 DOI: $10.1159 / 000495712$ 
Fig. 3. Drawings of Chelydra serpentina embryo showing the axial skeleton. A Lateral view: the anterior expression boundaries of the Hox genes reported by Ohya et al. [2005] are indicated. B Dorsal view indicating the axial formula. Red and blue staining show calcified and cartilage matrix, respectively. Printed from Gilbert et al. [2001] with permission from the authors. Drawing by Kathie Brown-Wing [Burke, 1989].

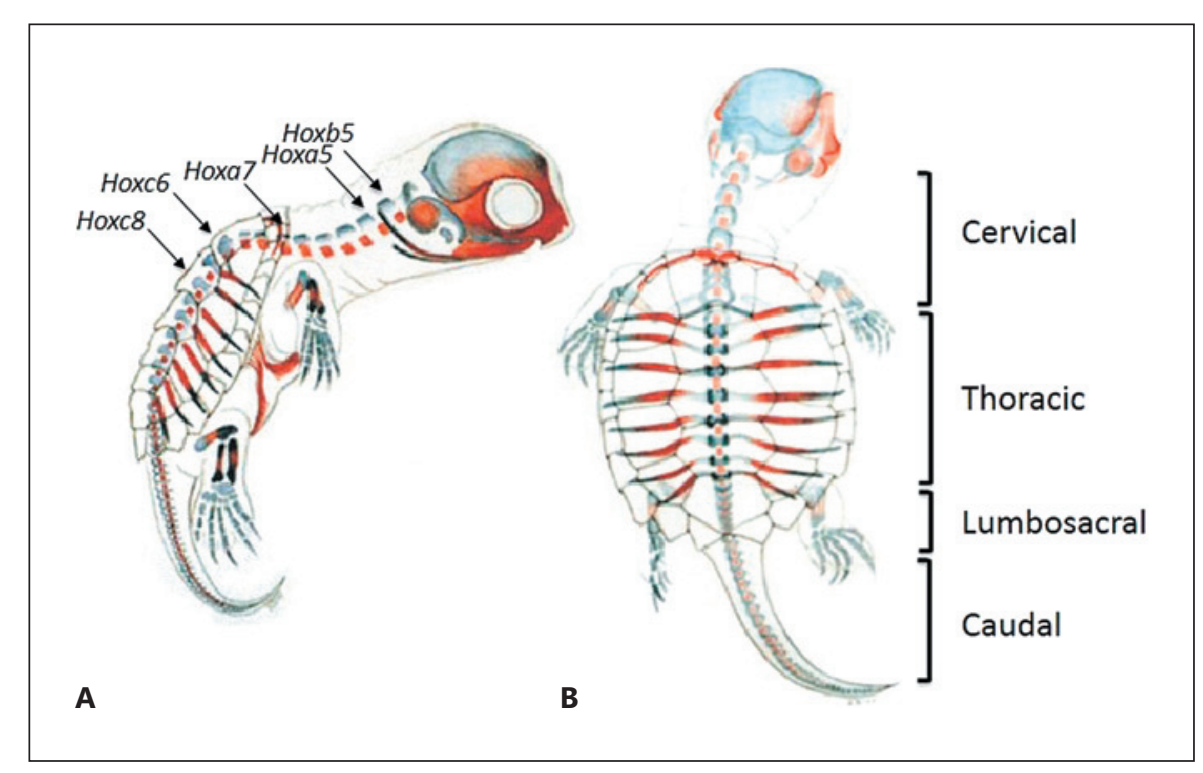

that has been conclusively demonstrated to determine sex in reptiles. This form of ESD is called temperature-dependent sex determination (TSD). Within the reptile group, all crocodiles and the 2 existing species of tuatara present TSD [Lang and Andrews, 1994; Deeming, 2004], as well as the vast majority of turtles [Merchant-Larios and DíazHernández, 2013]. All snakes present GSD [Matsubara et al., 2006], whereas lizards can present both GSD and TSD within the same family [Harlow, 2004]. For a comprehensive review on molecular mechanisms of sex determination and gonad differentiation in reptiles, see Rhen and Schroeder [2010].

Sea turtles lack sex chromosomes and display TSD [Merchant-Larios, 2001]. That is, a bipotential gonad will become ovary or testis depending on the incubation temperature of the eggs during a critical period of embryonic development, known as thermosensitive period (TSP), followed by the phenotypic differentiation of the gonad during the sex differentiation period (SDP) [MerchantLarios et al., 1997; Wibbels, 2003]. It has been suggested that Hoxa13 and Hoxd13 play regulatory roles in urogenital tract development in mammals [Scott et al., 2005], and some information has also been reported in turtles. Sifuentes-Romero et al. [2010] analyzed the quantitative and spatial expression patterns of Hoxd11 and Hoxa13 in the urogenital ridge of the olive ridley sea turtle (Lepidochelys olivacea) during TSP and SDP, at a male promoting temperature (MPT) and a female promoting temperature (FPT). In situ hybridization and quantitative PCR analysis revealed that at FPT the expression of Hoxd11 was downregulated from the TSP to the SDP, whereas at MPT Hoxd11 was expressed at similar levels at both periods. For Hoxa13, gene expression was significantly reduced in the gonad at FPT, while at MPT the expression was similar in both periods. The fact that Hoxa13 was expressed in the gonad during the TSP at FPT, and downregulated in the differentiated gonad suggests that this gene may be involved in the female developmental pathway rather than the male pathway. Additionally, expression of Hoxa13 in genital ducts was higher at MPT than at FPT, suggesting that Hoxa13 is involved in the maintenance of the wolffian duct and in the morphological changes leading to the partial regression of the müllerian duct in males [Sifuentes-Romero et al., 2010]. Complementarily, Leal and Cohn [2015] indicated that Hoxa13 and Hoxd13 show strong expression in the early hemipenis bud of the python, and later Hoxd13 becomes restricted to a subdistal domain of the hemipenis, where a hemipenial ridge arises, suggesting that Hoxal 13 and Hoxd 13 participate in the development of male genitalia in this species.

Mutational analysis in the mouse has demonstrated that Hoxa13 and Hoxd13 play an important role in the morphogenesis of the urogenital tract. For instance, Hoxa13-null mice show agenesis of the caudal portion of müllerian ducts and lack of development of the urinary bladder; Hoxa13 and Hoxd13 double-mutant mice show severely impaired development of the urogenital sinus and display no separation of the terminal (cloacal) hindgut cavity into a urogenital sinus and presumptive rectum [Warot et al., 1997]. Hoxa13 is also widely expressed in
38

Cytogenet Genome Res 2019;157:34-45 DOI: $10.1159 / 000495712$
Martín-del-Campo/Sifuentes-Romero/ García-Gasca 
the developing lower urogenital tract, and the hypodactyly mutation (which is a naturally occurring semidominant mutation that results from a 50-bp deletion in exon 1 of the Hoxa13 allele) results in reduction of branching in prostate ducts and abnormal seminal vesicle morphology [Podlasek et al., 1999].

Interestingly, sex determination in turtles seems to be epigenetically regulated since some studies have shown differential temperature-dependent DNA methylation levels between ovaries and testis in turtles presenting TSD [Matsumoto et al., 2013; 2016; Venegas et al., 2016; Radhakrishnan et al., 2017]. Likewise, epigenetic mechanisms may be involved in the regulation of gene expression networks defining shape in the early embryo.

\section{Hox Genes, Teratogenesis, and Environmental Influence}

Hox gene expression patterns strongly define reptile body plans. They provide the instructions to build a limbless snake or a turtle dorsalized trunk, yet changing environmental conditions may deliver different instructions with occasional modifications in body plan architecture. Most functional studies regarding Hox genes have been performed in animal models; nevertheless, several developmental defects observed in humans or generated by mutational analysis in mice have been documented in reptiles. For instance, Millichamp et al. [1983] identified microphtalmia in Nile crocodile (Crocodylus niloticus), Indian gharial (Gavialis gangeticus), Burmese python (Python molurus bivittataus), and boa constrictor (Boa constrictor). To a lesser extent, cyclopia and head malformations (cleft jaw and palate as well as shortening of the upper jaw) were also identified. Possible causes of such abnormalities may include genetic factors and suboptimal temperatures during incubation. Microphtalmia has been associated with mutations in the retinal homeoboxcontaining gene CHX10 in humans [Ferda Percin et al., 2000], whereas cleft palate has been identified in the mouse after disruption of Hoxa2 [Gendron-Maguire et al., 1993]. In addition, the homeobox gene Vax1 has been related to cleft palate and defects in the development of the visual system in the mouse [Hallonet et al., 1999]. Cyclopia is considered a rare congenital abnormality among reptiles. In Den Bosch and Musters [1987] described a cyclope of viperine snake (Natrix maura). This abnormal organism did not hatch, although the eggs were incubated under the same conditions as the other 3 eggs that developed normally. Cyclopia has also been reported in 1 olive

Hox Genes in Reptile Development ridley sea turtle (Lepidochelys olivacea) embryo from Sinaloa, Mexico. The embryo did not hatch, although other siblings within the same nest hatched normally [Bárcenas-Ibarra et al., 2015].

Reports regarding limb malformations and polydactyly in reptiles are sporadic: 1 Etheridge's lava lizard (Tropidurus etheridgei), caught in the Chaco Forest, Argentina [Pelegrin, 2007]; 1 common wall lizard (Podarcis muralis), caught in Southern Serbia [Lazić and CrnobrnjaIsailović, 2012]; 1 lizard (Liolaemus petrophilus), captured in the province of Chubut, Argentina [Minoli et al., 2009], and 1 gecko (Lepidodactylus sp.) collected in Tanager Islet, Palmyra Atoll, Line Islands [Bauer et al., 2009]. In addition, Adam [2012] reported limb abnormalities in 2 species of Australian scincid lizards (Lerista dorsalis and L. timida). The substantial proportion of asymmetric anomalies suggested that much of the phenotypic variation was environmentally induced.

Other limb abnormalities such as ectromelia of the forelimb have been identified in 2 Morelet crocodiles ( $C$. moreletii) captured in the New River system, Belize [Rainwater et al., 1999]. The authors identified the absence of the entire forearm including the scapula and procoracoid bones, ruling out limb loss due to trauma. Also, CupulMagaña et al. [2014] reported an atypical case of polymelia in a juvenile iguana captured in the urban area of Puerto Vallarta, Mexico. The animal showed a duplication of the left anterior extremity that defined the arm, forearm, and the 5 fingers with nails. Interestingly, Gehring [2009] reported a case of a living panther chameleon (Furcifer pardalis) from Madagascar. The specimen showed a very deformed vertebral column with a hump at the end of the thorax and a kink in the lumbar spine and pelvis, abnormal hind limbs leading to limited mobility, and a twisted tail with an accordion-like shape. Despite the severe physical malformations presented by the chameleon, it appeared to be in good condition and survived.

Mutational analysis in mice has revealed the importance of Hox genes in limb and digit development [Davis and Capecchi, 1996; Mortlock et al., 1996; Zákány and Duboule, 1996]. It is known that paralogue Hox13 genes are involved in digit formation since Hoxa13 and Hoxd13 double-mutant mice show polydactyly in the forelimbs [Fromental-Ramain et al., 1996], consisting of 7 symmetrically arranged, truncated, and mostly nonsegmented digits. Also, digit malformations (such as synpolydactily in humans) have been associated with mutations in Hoxd13 [Muragaki et al., 1996; Johnson et al., 1998].

In turtles, systematic studies describing and quantifying embryonic abnormalities in natural nesting areas

Cytogenet Genome Res 2019;157:34-45 DOI: $10.1159 / 000495712$ 
have been published. Drenen [1990] reported abnormalities in loggerhead sea turtle (Caretta caretta) embryos at Hobe Sound National Wildlife Refuge, Florida; cleft palate and appendix anomalies were the most common. Bishop et al. [1991] studied abnormal development in embryos and offspring of common snapping turtle (Chelydra serpentina) from the Great Lakes-St Lawrence River basin, reporting abnormalities in the carapace, tail, head, nails, and hip, among others, and suggested that some pollutants could be determining factors for abnormal developmental rates in turtles since concentrations of polychlorinated biphenyls (PCBs), polychlorinated dibenzodioxins (PCDDs), and polychlorinated dibenzofurans (PCDFs) in the eggs were related to the occurrence of abnormal embryos. Later, de Solla et al. [2007] reported abnormal development in snapping turtle hatchlings from different sites in the Canadian Lower Great Lakes; malformations in carapace, head, toes, and tail were documented, and the concentrations of PCBs, polybrominated diphenyl ethers (PBDEs), and pesticides in the eggs were measured; however, they did not report any association between contaminants and abnormal development. Bell et al. [2006] studied the development of snapping and painted turtle embryos in the John Heinz National Wildlife Refuge in Philadelphia, finding malformations in the tail, the carapace or plastron, the neural tube, and the craniofacial region; they also identified the presence of dwarfism. The authors reported that the developmental abnormalities identified were similar to those caused by pollutants such as polycyclic aromatic hydrocarbons (PAHs) [Van Meter et al., 2006], and were probably maternally transferred, since the chemical analysis of lipid samples from female turtles revealed significant levels of PAHs. This is relevant because xenobiotics show epigenetic effects by modifying DNA methylation during embryonic development, affecting epigenetic reprograming resulting either in congenital malformations and embryonic death (linage-specific methylation) or in transgenerational effects (germ-line-specific methylation) affecting reproduction and fertility [Anway and Skinner, 2006].

In olive ridley sea turtle embryos from Nuevo Vallarta, Mexico, Bárcenas-Ibarra and Maldonado-Gasca [2009] reported anomalies in the craniofacial region, the limbs, and the vertebral column. Palmieri et al. [2013] reported a case of bicephalic spur-thighed tortoise (Testudo graeca ibera) with multiple congenital abnormalities. The authors indicated that bicephaly is a rare malformation in Testudines and of unknown etiology. More recently, Bárcenas-Ibarra et al. [2015] carried out an extensive study on congenital malformations in olive ridley sea turtle em- bryos from Sinaloa, Mexico and green and hawksbill sea turtle embryos from the Yucatan peninsula in Mexico. The 3 species showed malformations in the craniofacial region, followed by the carapace and the limbs. Olive ridley embryos with multiple malformations were the most common. In addition, Bárcenas-Ibarra et al. [2016] reported the presence of schistosomus reflexus (SR) in olive ridley embryos, a malformative syndrome characterized by alterations in the abdominal wall and spine. The cause of SR is believed to be genetic; however, mercury concentrations seemed to be higher in malformed embryos (as compared to normal embryos), mostly in those with SR (unpublished data), suggesting a potential environmental influence as mercury is known to be teratogenic [Samson and Shenker, 2000].

Concerning genital abnormalities, females of the American alligator (Alligator mississippiensis) exhibited an abnormal ovarian morphology with a large number of poliovular follicles and polynuclear oocytes in a population of Lake Apopka, Florida, and males exhibited a significantly smaller penis compared to other populations [Guillette et al., 1994, 1996]. The authors concluded that estrogenic xenobiotics present in Lake Apopka (such as dichlorodiphenyltrichloroethane and metabolites) could produce such malformations since they have the potential to alter embryonic sexual development through a genetic or epigenetic disruption. In an interesting review, Walker [2016] presented experimental studies performed in mice exposed to endocrine disrupting compounds. Such studies demonstrated the vulnerability of the epigenome in the presence of environmental insults. Endocrine disrupting compounds seem to reprogram the epigenome by altering availability of methyl donors, loss of imprinting control, changes in dioxygenase activity, altered expression of ncRNAs, and activation of cell signaling pathways.

Hox genes play an important role in the morphogenesis of the urogenital tract [Scott et al., 2005], and experimental essays have shown that some contaminants modify the expression of these genes. In vivo treatment of mice with the organochlorine pesticide methoxychlor reduced the expression of Hoxa10 [Fei et al., 2005], a gene required for uterine development and function [Taylor et al., 1997], producing mild uterotropic response as measured by increased uterine weight and epithelial height. Methoxychlor allowed weak estrogen receptor (ER)/estrogen response element (ERE) binding, producing defects in the reproductive tract due to altered gene expression during development [Fei et al., 2005]. It is known that some Hox genes (such as Hoxc6) are responsive to estrogen [Garcia-Gasca and Spyropuolos, 2000]; there-
40

Cytogenet Genome Res 2019;157:34-45 DOI: $10.1159 / 000495712$
Martín-del-Campo/Sifuentes-Romero/ García-Gasca 
fore, it is likely that Hox genes would also be responsive to endocrine disrupting compounds.

Kojima and Takahashi [2009] analyzed the expression changes of the 39 Hox genes in tetrachlorodibenzo-p-dioxin (TCDD)-retinoic acid (RA)-exposed mouse embryos. The authors identified that both teratogenic agents differentially affected the expression of Hox genes, but unlike RA, TCDD showed a broad repression of all Hox loci. The authors detected several phenotypes, such as craniofacial anomalies and kidney defects, and concluded that the irregular expression of Hox genes was responsible for congenital anomalies. Also, Waxman and Yelon [2009] overexpressed Hoxb5b in zebrafish embryos, and treated the embryos with RA, observing that increased RA signaling and Hox activity cause abnormal body axis phenotypes, such as loss or reduction of the head and tail truncation.

Congenital abnormalities associated with environmental conditions in captive reptiles have also been reported. In captive vipers, Mulder [1995] identified congenital abnormalities in the spine and the craniofacial region, among other morphological anomalies. The author suggested that many of the congenital abnormalities could be due to reproduction in captivity considering the artificial environment. Some experimental studies indicate that abnormal temperatures during incubation influence the incidence of congenital anomalies. For example, in pine snake (Pituophis melanoleucus), abnormality rates varied significantly as a function of the incubation temperature [Burger et al., 1987]. Eggs incubated at lower temperatures presented congenital anomalies such as ventral hernias, enlarged or desiccated eyes, kinked tails or bodies, and skin growths on the head or neck. Eggs incubated at higher temperatures did not show congenital anomalies, but a lower hatching rate than eggs incubated at intermediate temperatures. In the Oriental Garden Lizard (Calotes versicolor), higher incubation temperatures produced smaller individuals with shorter heads and hind limbs as well as shorter tympanum and eye diameters relative to those incubated at intermediate temperatures [Ji et al., 2002]. Steyermark and Spotila [2001] also reported that suboptimal incubation temperatures cause malformations in C. serpentina, such as tail abnormalities. More recently, Telemeco et al. [2013] reported that exposure of painted turtle (Chrysemys picta) embryos to hot temperatures for more than 60 hours produce hatchlings with deformities in the carapace, whereas no abnormalities were observed after exposure to cold temperatures suggesting that sustained hot temperatures reduce the rate of development by disrupting molecular interactions leading to abnormal phenotypes.

Hox Genes in Reptile Development
Humidity during the incubation period may also play an important role in teratogenesis. Lynn and Ullrich [1950] found that eggs of the eastern painted turtle (C. picta picta) and the snapping turtle exposed to changes in moisture conditions during certain developmental stages often gave rise to offspring presenting various types of congenital abnormalities, such as asymmetric carapace, abnormal scutellation, jaw anomalies, and eyeless and mouthless stump. More recently, Zimm et al. [2017] reported a synergistic effect of high temperatures and dry conditions in the development of abnormal scutellation patterns in turtles. This is important because both factors (temperature and humidity) interact affecting reptile development at different levels, from endocrine regulation and sex determination to body and craniofacial architecture.

\section{Epigenetic Regulation of Hox Genes}

It is clear that environmental conditions strongly affect anteroposterior and appendicular body plans in reptiles as well as urogenital tract development and sex determination suggesting that epigenetic mechanisms are involved in Hox gene regulation [Soshnikova and Duboule, 2009; Barber and Rastegar, 2010]. It is tempting to think that temperature and humidity (among other factors) affect reptile development through subtle epigenetic changes in Hox genes with not-so-subtle phenotypic implications.

Some epigenetic mechanisms for Hox gene regulation have been reported. For instance, it is known that key developmental genes that are inactive in embryonic stem (ES) cells possess both "active" (i.e., methylation of histone 3 at lysine $4-\mathrm{H} 3 \mathrm{~K} 4 \mathrm{me}-$ ) and "inactive" (i.e., methylation of histone 3 at lysine 27 -H3K27me-) histone marks. This group of genes presents the so-called "bivalent chromatin tags" [Bernstein et al., 2006], and among them are the members of the 4 Hox groups with bivalent chromatin labels and transcriptional states repressed in pluripotent ES cells [Barber and Rastegar, 2010]. These chromatin modifications lead to changes in the accessibility of trans-acting factors that bind to cis-elements [Kojima and Takahashi, 2012]. Two groups of proteins acting in opposite directions maintain the transcriptional state of Hox genes: transcription-activating proteins from the Trithorax (TrxG) group and transcription-repressing proteins from the Polycomb (PcG) group [Schuettengruber et al., 2011].

Polycomb proteins repress the expression of their targets through 2 major protein complexes: PRC1 and PRC2

Cytogenet Genome Res 2019;157:34-45 DOI: $10.1159 / 000495712$ 
Fig. 4. Mechanisms of teratogenesis in turtle embryos. The embryo receives nutrients, hormones, and other compounds (including xenobiotics) from the mother through the yolk. In addition, embryos are partially exposed to the external environment through the shell and the chorion. Besides heredity factors (the genetic pool), both maternal transfer and incubation conditions may act on the DNA causing mutations or epigenetic modifications, which may in turn cause dysregulation of Hox and other developmental genes producing teratogenesis and, in most cases, embryonic death.

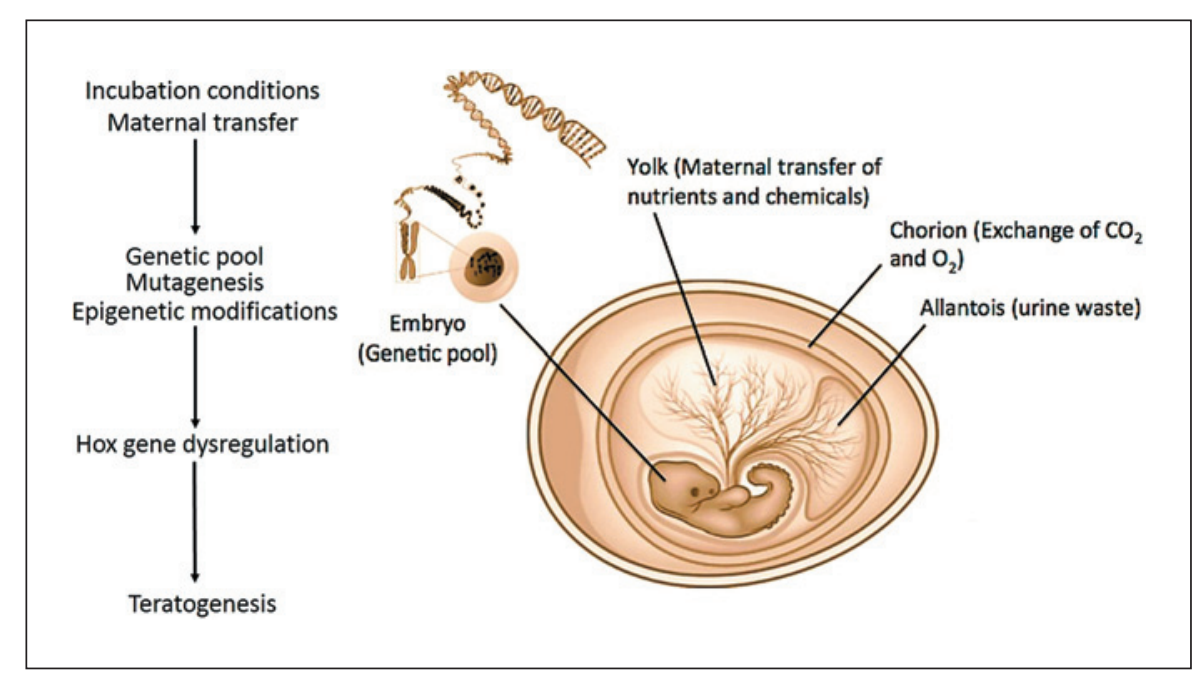

(polycomb-group repressive complex 1 and 2, respectively). These repressive complexes modulate gene expression not only of Hox genes, but also of other genes with important developmental functions [Boyer et al., 2006]. PRC2 inhibits initial transcription by catalyzing the (diand tri-) methylation of H3K27 [Cao et al., 2002; Kirmizis et al., 2004; Lee et al., 2006]; the functions of PRC2 in ES cells to repress Hox and other developmental genes are preferably activated during differentiation [Lee et al., 2006]. The PRC1 complex catalyzes the mono-ubiquitination of H2AK119, enhancing chromatin condensation in order to maintain gene silencing [Cao et al., 2002; Wang et al., 2004; Barber and Rastegar, 2010]. PcG proteins repress Hox genes, and disrupting PcG genes result in ectopic Hox gene expression [Bello et al., 2007]. TrxG proteins antagonize PcG proteins and stimulate expression of Hox genes [Barber and Rastegar, 2010; Schuettengruber et al., 2011]. The first protein member of the TrxG family identified as a positive regulator of Hox genes was Trx (human MLL homologue), the function of this protein is not necessarily to initiate Hox gene expression, but rather to maintain gene expression in appropriate body segments later in development [Schuettengruber et al., 2011].

The COMPASS proteins, which are part of the TrxG family [complex proteins associated with SET domaincontaining 1 (SET1)], belong to the histone methyltransferase group and catalyze the mono-, di- and trimethylation of $\mathrm{H} 3 \mathrm{~K} 4$ through its conserved SET domain; this methylation is a hallmark of active genes [Schuettengruber et al., 2011]. SET1 was the first identified COMPASS protein in yeast. Later, the MLL1 COMPASS-like protein was identified in mammals and, together with MLL2, is required for H3K4 trimethylation of Hox genes [Wu et al., 2008; Schuettengruber et al., 2011]. MLL3 and MLL4containing complexes have demethylase activity and can remove PcG-mediated repressive $\mathrm{H} 3 \mathrm{~K} 27$ methylation [Lee et al., 2007]. The deletion of the conserved SET domain in MLL by homologous recombination in ES cells in mice causes reduction in $\mathrm{H} 3 \mathrm{~K} 4$ monomethylation and DNA methylation defects at the same Hox loci, inducing gene repression [Terranova et al., 2006].

TrxG proteins can be recruited to their targets via their interaction with noncoding RNAs (ncRNAs). Long intergenic noncoding RNAs (lincRNAs), many of which are implicated in gene silencing, can perform an enhancerlike function acting over long distances to activate gene expression [Ørom et al., 2010; Schuettengruber et al., 2011]. The HOTTIP (HOXA transcript at the distal tip) long noncoding RNA binds and targets WDR5-MLL complexes across the HoxA locus to induce H3K4 trimethylation and gene activation [Wang et al., 2011].

\section{Concluding Remarks}

Reptiles show very different shapes. During early development, Hox genes establish the anteroposterior design of reptile body plans resulting in very particular phenotypes (such as the limbless, elongated body of the snake, and the turtle dorsalized ribs or retractile neck). Genetic and epigenetic mechanisms work together to orchestrate reptile development through activation and repression of key developmental genes. Because the incu- 
bation environment (both the mother and the nest) is crucial in reptile development, any environmental insult during critical periods of development will alter normal Hox gene expression resulting in developmental abnormalities, and most likely embryonic death (Fig. 4). Thus, understanding the effects of the environment in developmental outcomes of reptiles at both genetic and epigenetic levels will help establish causal relations between environment and phenotype (Fig. 4). This is not a trivial task since most reptiles are not model organisms and unravelling developmental networks in wild popula- tions represents a big challenge. Current sequencing technologies allow the study of non-model organisms through the interrogation of the whole genome by comparing transcriptomes, exomes, or epigenomes under different incubation, reproduction or feeding environments, thus providing the evidence required to link nature and nurture. Several reptile genomes and transcriptomes have already been sequenced, and novel information regarding the influence of the environment on developmental anomalies in a variety of reptile species is around the corner.

\section{References}

Adam S: Limb abnormalities in two species of Lerista (Scincidae, Squamata). Curr Herpetol 31:1-7 (2012).

Anway MD, Skinner MK: Epigenetic transgenerational actions of endocrine disruptors. Endocrinology 147 (6 Suppl):S43-S49 (2006).

Barber BA, Rastegar M: Epigenetic control of Hox genes during neurogenesis, development, and disease. Ann Anat 192:261-274 (2010).

Bárcenas-Ibarra A, Maldonado-Gasca A: Malformaciones en embriones y neonatos de tortuga golfina (Lepidochelys olivacea) en Nuevo Vallarta, Nayarit, México. Vet Mex 40:371-380 (2009).

Bárcenas-Ibarra A, De la Cueva H, Rojas-Lleonart I, Abreu-Grobois FA, Lozano-Guzmán RI, et al: First approximation to congenital malformation rates in embryos and hatchlings of sea turtles. Birth Defects Res A Clin Mol Teratol 103:203-224 (2015).

Bárcenas-Ibarra A, Rojas-Lleonart I, LozanoGuzmán RI, García-Gasca A: Schistosomus reflexus syndrome in olive ridley sea turtles (Lepidochelys olivacea). Vet Pathol 54:171177 (2016).

Bauer AM, Hathaway SA, Fisher RN: Polydactyly in the Central Pacific Gecko, Lepidodactylus sp. (Squamata: Gekkonidae). Herpetol Notes 2:243-246 (2009).

Bell B, Spotila JR, Congdon J: High incidence of deformity in aquatic turtles in the John Heinz National Wildlife Refuge. Environ Pollut 142: 457-465 (2006).

Bello B, Holbro N, Reichert H: Polycomb group genes are required for neural stem cell survival in postembryonic neurogenesis of Drosophila. Development 134:1091-1099 (2007).

Bernstein BE, Mikkelsen TS, Xie X, Kamal M, Huebert DJ, et al: A bivalent chromatin structure marks key developmental genes in embryonic stem cells. Cell 125:315-326 (2006).
Bishop CA, Brooks RJ, Carey JH, Ng P, Norstrom RJ, Lean DR: The case for a cause-effect linkage between environmental contamination and development in eggs of the common snapping turtle (Chelydra serpentina) from Ontario, Canada. J Toxicol Environ Health 33:521-547 (1991).

Böhmer C, Werneburg I: Deep time perspective on turtle neck evolution: chasing the Hox code by vertebral morphology. Sci Rep 7:8938 (2017).

Boyer LA, Plath K, Zeitlinger J, Brambrink T, Medeiros LA, et al: Polycomb complexes repress developmental regulators in murine embryonic stem cells. Nature 441:349-353 (2006).

Burger J, Zappalorti RT, Gochfeld M: Developmental effects of incubation temperature on hatchling pine snakes Pituophis melanoleucus. Comp Biochem Phys A 87:727-732 (1987).

Burke AC: Critical features in Chelonian development: the ontogeny and phylogeny of a unique tetrapod bauplan. (PhD thesis, Harvard University, Cambridge, 1989).

Burke AC, Nelson CE, Morgan BA, Tabin C: Hox genes and the evolution of vertebrate axial morphology. Development 121:333-346 (1995).

Cao R, Wang L, Wang H, Xia L, Erdjument-Bromage $\mathrm{H}$, et al: Role of histone $\mathrm{H} 3$ lysine 27 methylation in polycomb group silencing. Science 298:1039-1043 (2002).

Carapuço M, Nóvoa A, Bobola N, Mallo M: Hox genes specify vertebral types in the presomitic mesoderm. Gene Dev 19:2116-2121 (2005).

Cohn MJ, Tickle C: Developmental basis of limblessness and axial patterning in snakes. Nature 399:474-479 (1999).

Cohn MJ, Patel K, Krimlauf R, Wilkinson DG, Clarke JD, Tickle C: Hox9 genes and vertebrate limb specification. Nature 387:97-101 (1997).
Cupul-Magaña FG, García de Quevedo-Machain R, Tovar-Ramos JA, Curiel-Beltrán JA: Duplicación de miembro anterior en Iguana iguana (Linnaeus, 1758): registro de caso. Cuad Herpetol 28:33-34 (2014).

Davis AP, Capecchi MR: A mutational analysis of the $5^{\prime}$ HoxD genes: dissection of genetic interactions during limb development in the mouse. Development 122:1175-1185 (1996).

Deeming DC: Prevalence of TSD in crocodilians, in Valenzuela N, Lance VA (eds): Temperature-Dependent Sex Determination in Vertebrates, pp 33-41 (Smithsonian Institution Press, Washington 2004).

Deeming DC, Ferguson MW: Physiological effects of incubation temperature on embryonic development in reptiles and birds, in Deeming DC, Ferguson MW (eds): Egg Incubation: Its Effects on Embryonic Development in Birds and Reptiles, pp 147-171 (Cambridge University Press, Cambridge 1991).

de Solla SR, Fernie KJ, Ashpole S: Snapping turtles (Chelydra serpentina) as bioindicators in Canadian Areas of Concern in the Great Lakes Basin. II. Changes in hatching success and hatchling deformities in relation to persistent organic pollutants. Environ Pollut 153:529536 (2007).

Di-Poï N, Montoya-Burgos JI, Miller H, Pourquié $\mathrm{O}$, Milinkovitch MC, Duboule D: Changes in Hox genes' structure and function during the evolution of the squamate body plan. Nature 464:99-103 (2010).

Drenen JD: Occurrence of physical abnormalities in Caretta caretta at Hobe Sound National Wildlife Refuge, 1987 and 1988. Mar Turt Newsl 48:19-20 (1990).

Fei X, Chung H, Taylor HS: Methoxychlor disrupts uterine Hoxa10 gene expression. Endocrinology 146:3445-3451 (2005).

Ferda Percin E, Ploder LA, Yu JJ, Arici K, Horsford DJ, et al: Human microphthalmia associated with mutations in the retinal homeobox gene CHX10. Nat Genet 25:397-401 (2000). 
Fromental-Ramain C, Warot X, Messadecq N, LeMeur M, Dollé P, Chambon P: Hoxa-13 and Hoxd-13 play a crucial role in the patterning of the limb autopod. Development 122: 2997-3011 (1996).

Gaffney ES: The comparative osteology of the Triassic turtle Proganochelys. B Am Mus Nat Hist 194:1-263 (1990).

Garcia-Gasca A, Spyropoulos D: Differential mammary morphogenesis along the anteroposterior axis in Hoxc6 gene targeted mice. Dev Dyn 219:261-276 (2000).

Gaunt SJ: Conservation in the Hox code during morphological evolution. Int J Dev Biol 38: 549-552 (1994).

Gehring PS: A remarkable case of malformation in a free-living individual of Furcifer pardalis (Cuvier, 1829) from northern Madagascar. Herpetol Notes 2:223-225 (2009).

Gendron-Maguire M, Mallo M, Zhang M, Gridley T: Hoxa-2 mutant mice exhibit homeotic transformation of skeletal elements derived from cranial neural crest. Cell 75:1317-1331 (1993).

Gilbert SF: Developmental Biology, ed 9, pp 413415 (Sinauer Associates Inc, Sunderland 2010)

Gilbert SF, Loredo GA, Brukman A, Burke AC: Morphogenesis of the turtle shell: the development of a novel structure in tetrapod evolution. Evol Dev 3:47-58 (2001).

Gilbert SF, Cebra-Thomas JA, Burke AC: How the turtle gets its shell, in Wyneken J, Godfrey MH, Bels V (eds): Biology of Turtles, pp 1-16 (CRC Press, Boca Raton 2008).

Gomez C, Özbudak EM, Wunderlich J, Baumann $\mathrm{D}$, Lewis J, Pourquié O: Control of segment number in vertebrate embryos. Nature 454 : 335-339 (2008).

Guillette LJ Jr, Gross TS, Masson GR, Matter JM, Percival HF, Woodward AR: Developmental abnormalities of the gonad and abnormal sex hormone concentrations in juvenile alligators from contaminated and control lakes in Florida. Environ Health Perspect 102:680 (1994).

Guillette LJ Jr, Pickford DB, Crain DA, Rooney AA, Percival HF: Reduction in penis size and plasma testosterone concentrations in juvenile alligators living in a contaminated environment. Gen Comp Endocrinol 101:32-42 (1996).

Hallonet M, Hollemann T, Pieler T, Gruss P: Vax1, a novel homeobox-containing gene, directs development of the basal forebrain and visual system. Genes Dev 13:3106-3114 (1999).

Harlow PS: Temperature-dependent sex determination in lizards, in Valenzuela N, Lance VA (eds): Temperature-Dependent Sex Determination in Vertebrates, pp 42-52 (Smithsonian Institution Press, Washington 2004).

Hirasawa T, Nagashima H, Kuratani S: The endoskeletal origin of the turtle carapace. Nat Commun 4:2107 (2013).

In Den Bosch HAJ, Musters CJM: Scalation and skull morphology of a cyclopean Natrix Maura. J Herpetol 21:107-114 (1987).
Ji X, Qiu QB, Diong CH: Influence of incubation temperature on hatching success, energy expenditure for embryonic development, and size and morphology of hatchlings in the oriental garden lizard, Calotes versicolor (Agamidae). J Exp Zool 292:649-659 (2002).

Johnson KR, Sweet HO, Donahue LR, Ward-Bailey P, Bronson RT, Davisson MT: A new spontaneous mouse mutation of Hoxd13 with a polyalanine expansion and phenotype similar to human synpolydactyly. Hum Mol Genet 7:1033-1038 (1998).

Jones MEH, Werneburg I, Curtis N, Penrose R, O'Higgins P, et al: The head and neck anatomy of sea turtles (Cryptodira: Chelonioidea) and skull shape in testudines. PLoS One 7:e47852 (2012).

Kirmizis A, Bartley SM, Kuzmichev A, Margueron R, Reinberg D, et al: Silencing of human polycomb target genes is associated with methylation of histone H3 Lys 27. Genes Dev 18:1592-1605 (2004).

Kojima T, Takahashi N: Influence of teratogenic factors on mouse 39 hox gene expression. Biosci Biotechnol Biochem 73:2416-2421 (2009).

Kojima T, Takahashi N: Hox genes and teratogenic factors, in Sutcliffe A (ed): Congenital Anomalies - Case Studies and Mechanisms, Chapter 1 (INTECH Open Access Publisher 2012).

Kuraku S, Usuda R, Kuratani S: Comprehensive survey of carapacial ridge-specific genes in turtle implies co-option of some regulatory genes in carapace evolution. Evol Dev 7:3-17 (2005).

Kvon EZ, Kamneva OK, Melo US, Barozzi I, Osterwalder M, et al: Progressive loss of function in a limb enhancer during snake evolution. Cell 167:633-642 (2016).

Lang JW, Andrews HV: Temperature-dependent sex determination in crocodilians. J Exp Zool 270:28-44 (1994).

Lazić MM, Crnobrnja-Isailović J: Polydactyly in the common wall lizard Podarcis muralis (Squamata: Lacertidae). Herpetol Notes 5: 277-279 (2012).

Leal F, Cohn MJ: Development of hemipenes in the ball python snake Python regius. Sex Dev 9:6-20 (2015).

Leal F, Cohn MJ: Loss and re-emergence of legs in snakes by modular evolution of Sonic hedgehog and HOXD enhancers. Curr Biol 26: 2966-2973 (2016).

Lee MG, Villa R, Trojer P, Norman J, Yan KP, et al: Demethylation of $\mathrm{H} 3 \mathrm{~K} 27$ regulates polycomb recruitment and $\mathrm{H} 2 \mathrm{~A}$ ubiquitination. Science 318:447-450 (2007).

Lee TI, Jenner RG, Boyer LA, Guenther MG, Levine SS, et al: Control of developmental regulators by Polycomb in human embryonic stem cells. Cell 125:301-313 (2006).

Lewis EB: A gene complex controlling segmentation in Drosophila. Nature 276:565-570 (1978).
Li C, Wu XC, Rieppel O, Wang LT, Zhao LJ: An ancestral turtle from the Late Triassic of southwestern China. Nature 456:497-501 (2008).

Liang D, Wu R, Geng J, Wang C, Zhang P: A general scenario of Hox gene inventory variation among major sarcopterygian lineages. BMC Evol Biol 11:25 (2011).

Lonfat N, Montavon T, Darbellay F, Gitto S, Duboule D: Convergent evolution of complex regulatory landscapes and pleiotropy at Hox loci. Science 346:1004-1006 (2014).

Lynn WG, Ullrich MC: Experimental production of shell abnormalities in turtles. Copeia 4: 253-262 (1950).

Mallo M, Wellik DM, Deschamps J: Hox genes and regional patterning of the vertebrate body plan. Dev Biol 344:7-15 (2010).

Matsubara K, Tarui H, Toriba M, Yamada K, Nishida-Umehara C, et al: Evidence for different origin of sex chromosomes in snakes, birds, and mammals and step-wise differentiation of snake sex chromosomes. Proc Natl Acad Sci USA 103:18190-18195 (2006).

Matsumoto Y, Buemio A, Chu R, Vafaee M, Crews D: Epigenetic control of gonadal aromatase (cyp19a1) in temperature-dependent sex determination of red-eared slider turtles. PLoS One 8:e63599 (2013).

Matsumoto Y, Hannigan B, Crews D: Temperature shifts alters DNA methylation and histone modification patterns in gonadal aromatase (cyp19a1) gene in species with temperature-dependent sex determination. PLoS One 11:e0167362 (2016).

Merchant-Larios H: Temperature sex determination in reptiles: the third strategy. J Reprod Dev 47:245-252 (2001).

Merchant-Larios H, Díaz-Hernández V: Environmental sex determination mechanisms in reptiles. Sex Dev 7:95-103 (2013).

Merchant-Larios H, Ruiz-Ramírez S, MorenoMendoza N, Marmolejo-Valencia A: Correlation among thermosensitive period, estradiol response, and gonad differentiation in the sea turtle Lepidochelys olivacea. Gen Comp Endocr 107:373-385 (1997).

Millichamp NJ, Jacobson ER, Wolf ED: Diseases of the eye and ocular adnexa in reptiles. J Am Vet Med Assoc 183:1205-1212 (1983).

Minoli I, Feltrin N, Ávila LJ: Un caso de polidactilia en Liolaemus petrophilus (Iguania: Squamata: Liolaemini). Cuad herpetol 23:89-92 (2009).

Montavon T, Soshnikova N, Mascrez B, Joye E, Thevenet L, et al: A regulatory archipelago controls Hox genes transcription in digits. Cell 147:1132-1145 (2011).

Mortlock DP, Post LC, Innis JW: The molecular basis of hypodactyly (Hd): a deletion in Hoxa13 leads to arrest of digital arch formation. Nat Genet 13:284-289 (1996).

Mulder J: Congenital anomalies in morphology and colour in captive-bred vipers (Reptilia, Serpentes, Viperidae). Deinsea 2:41-50 (1995). 
Muragaki Y, Mundlos S, Upton J, Olsen BR: Altered growth and branching patterns in synpolydactyly caused by mutations in HOXD13. Science 272:548-551 (1996).

Nagashima H, Kuraku S, Uchida K, Ohya YK, Narita Y, Kuratani S: On the carapacial ridge in turtle embryos: its developmental origin, function and the chelonian body plan. Development 134:2219-2226 (2007).

Nelson CE, Morgan BA, Burke AC, Laufer E, DiMambro E, et al: Analysis of Hox gene expression in the chick limb bud. Development 122: 1449-1466 (1996).

Ohya YK, Kuraku S, Kuratani S: Hox code in embryos of Chinese soft shelled turtle Pelodiscus sinensis correlates with the evolutionary innovation in the turtle. J Exp Zool B Mol Dev Evol 304:107-118 (2005)

Ørom UA, Derrien T, Beringer M, Gumireddy K, Gardini A: Long noncoding RNAs with enhancer-like function in human cells. Cell 143: 46-58 (2010).

Palmieri C, Selleri P, Di Girolamo N, Montani A, Della Salda L: Multiple congenital malformations in a dicephalic spur-thighed tortoise (Testudo graeca ibera). J Comp Pathol 149: 368-371 (2013).

Pelegrin N: Presence of a polydactylous Tropidurus etheridgei (Squamata: Iguanidae: Tropidurinae) in the dry Chaco of Córdoba province, Argentina. Cuad Herpetol 21:115-116 (2007).

Podlasek CA, Clemens JQ, Bushman W: Hoxa-13 gene mutation results in abnormal seminal vesicle and prostate development. J Urol 161: 1655-1661 (1999).

Radhakrishnan S, Literman R, Mizoguchi B, Valenzuela N: MeDIP-seq and $\mathrm{nCpG}$ analyses illuminate sexually dimorphic methylation of gonadal development genes with high historic methylation in turtle hatchlings with temperature dependent sex determination. Epigenetics Chromatin 10:28 (2017).

Rainwater TR, McMurry ST, Platt SG: Ectromelia in Morelet's crocodile from Belize. J Wildl Dis 35:125-129 (1999).

Rancourt DE, Tsuzuki T, Capecchi MR: Genetic interaction between Hoxb-5 and Hoxb-6 is revealed by nonallelic noncomplementation. Genes Dev 9:108-122 (1995).

Rhen T, Schroeder A: Molecular mechanisms of sex determination in reptiles. Sex Dev 4:1628 (2010).
Samson J, Shenker J: The teratogenic effects of methylmercury on early development of the zebrafish, Danio rerio. Aquat Toxicol 48:343354 (2000).

Schoenwolf GC, Smith JL: Gastrulation and early mesodermal patterning in vertebrates. Methods Mol Biol 135:113-125 (2000).

Schuettengruber B, Martinez AM, Iovino N, Cavalli G: Trithorax group proteins: switching genes on and keeping them active. Nat Rev Mol Cell Biol 12:799-814 (2011).

Scott V, Morgan EA, Stadler HS: Genitourinary functions of Hoxa13 and Hoxd13. J Biochem 137:671-676 (2005).

Sifuentes-Romero I, Merchant-Larios H, GarcíaGasca A: Hox gene expression in the embryonic genital system of the sea turtle Lepidochelys olivacea (Eschscholtz, 1829), a species with temperature-dependent sex determination. Gene Expr Patterns 10:290-298 (2010).

Soshnikova N, Duboule D: Epigenetic temporal control of mouse Hox genes in vivo. Science 324:1320-1323 (2009).

Steyermark AC, Spotila, JR: Effects of maternal identity and incubation temperature on hatching and hatchling morphology in snapping turtles, Chelydra serpentina. Copeia 2001:129-135 (2001).

Taylor HS, Vanden Heuvel GB, Igarashi P: A conserved Hox axis in the mouse and human female reproductive system: late establishment and persistent adult expression of the hoxa cluster genes. Biol Reprod 57:1338-1345 (1997).

Telemeco RS, Warner DA, Reida MK, Janzen FJ: Extreme developmental temperatures result in morphological abnormalities in painted turtles (Chrysemys picta): a climate change perspective. Integr Zool 8:197-208 (2013).

Terranova R, Agherbi H, Boned A, Meresse S, Djabali M: Histone and DNA methylation defects at Hox genes in mice expressing a SET domain-truncated form of Mll. Proc Natl Acad Sci USA 103:6629-6634 (2006).

Van Meter RJ, Spotila JR, Avery HW: Polycyclic aromatic hydrocarbons affect survival and development of common snapping turtle (Chelydra serpentina) embryos and hatchlings. Environ Pollut 142:466-475 (2006).
Venegas D, Marmolejo-Valencia A, ValdesQuezada C, Govenzensky T, Recillas-Targa F, Merchant-Larios H: Dimorphic DNA methylation during temperature-dependent sex determination in the sea turtle Lepidochelys olivacea. Gen Comp Endocrinol 236:35-41 (2016).

Vincent C, Bontoux M, Le Douarin NM, Pieau C, Monsoro-Burq AH: Msx genes are expressed in the carapacial ridge of turtle shell: a study of the European pond turtle, Emys orbicularis. Dev Genes Evol 213:464-469 (2003).

Walker CL: Minireview: Epigenomic plasticity and vulnerability to EDC exposures. Mol Endocrinol 30:848-855 (2016).

Wang H, Wang L, Erdjument-Bromage H, Vidal $\mathrm{M}$, Tempst P, et al: Role of histone H2A ubiquitination in Polycomb silencing. Nature 431: 873-878 (2004).

Wang KC, Yang YW, Liu B, Sanyal A, CorcesZimmerman $\mathrm{R}$, et al: A long noncoding RNA maintains active chromatin to coordinate homeotic gene expression. Nature 472:120124 (2011).

Warot X, Fromental-Ramain C, Fraulob V, Chambon P, Dollé P: Gene dosage-dependent effects of the Hoxa-13 and Hoxd-13 mutations on morphogenesis of the terminal parts of the digestive and urogenital tracts. Development 124:4781-4791 (1997).

Waxman JS, Yelon D: Increased Hox activity mimics the teratogenic effects of excess retinoic acid signaling. Dev Dyn 238:1207-1213 (2009).

Wibbels T: Critical approaches to sex determination turtles, in Lutz PL, Musik JA, Wineken J (eds): The Biology of Sea Turtles, vol. 2, pp 103-134 (CRC Press, Boca Raton 2003).

Wu MP, Wang JS, Lee S, Martin-Brown L, Florens $\mathrm{M}$, et al: Molecular regulation of $\mathrm{H} 3 \mathrm{~K} 4$ trimethylation by $W d r 82$, a component of human Set1/ COMPASS. Mol Cell Biol 28:73377344 (2008).

Zákány J, Duboule D: Synpolydactyly in mice with a targeted disruption in the HoxD complex. Nature 384:69-71 (1996).

Zimm R, Bentley BP, Wyneken J, MoustakasVerho JE: Environmental causation of turtle scute anomalies in ovo and in silico. Integr Comp Biol 57:1303-1311 (2017). 